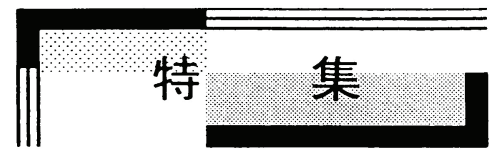

地球惑星科学の混相流 ーキッチン地球科学の視点からー*

Multiphase Flow in Earth and Planetary Sciences Viewed from Kitchen Earth Science

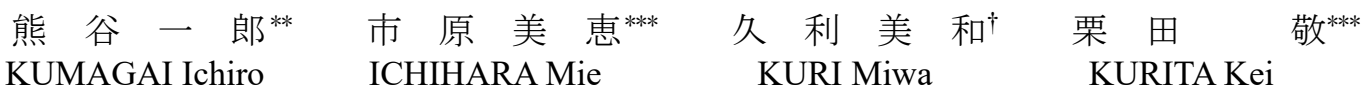

\begin{abstract}
Kitchen Earth Science," which is scientific, educational, and public outreach activities, aims at understanding a natural phenomenon in Earth and planetary sciences by analogue experiments using goods and tools in our daily life. Analogue experiments have a function to reveal the fundamental physics governing the phenomenon. On the other hand, they essentially include uncertainties so that unexpected results are frequently obtained, which have a potential for surprising discoveries. These findings also provide a good opportunity for deeply thinking and raise new questions to explore. Such experiences are precious not only for young researchers, but also non-expert people who need a scientific thinking to live wisely. Here, we introduce our recent activities of "Kitchen Earth Science" and the experimental studies rerated to the multiphase flow in Earth and planetary sciences.
\end{abstract}

Keywords: Kitchen earth science, Hands-on experiments, Multiphase flow, Scientific education, Earth and planetary sciences

\section{1. はじめにー本特集の経緯}

昨年 4 月、編集委員の渡村友昭先生 (大阪大学) より本企画のお誘いを頂戴した。渡村さん（研究 集会では上下関係なく、基本「〜さん」で呼び合 う) とは、熊谷が北海道大学 (工学研究院流れ制 御研究室) に所属していた頃からお付き合いをさ せて頂いている。「キッチン地球科学」との関係 では、2017 年 (キッチン地球科学研究集会、東 京大学地震研究所）と 2018 年（日本地球惑星科 学連合大会、幕張メッセ）において「ギネスビー ルの泡のパターン形成」に関するご講演を頂いた

(Photo 1、内容については[1]を参照)。渡村さん は流体工学の専門家としてこの問題に取り組ん でおられたが、地球惑星科学分野においても、ビ 一ルやコーラなどの炭酸飲料は、火山の噴火現象 と結びつけて考えることが多く（例えば[2]）、研 究集会では分野を超えて自由闊達な議論が交わ
された (その後の懇親会では、実際にビールを飲 みながら議論した)。

「キッチン地球科学」とは何なのかを感じ取っ て頂くために、本稿の最後に、最近 3 年間のキッ チン地球科学の講演題目リストを掲載させて頂 いた（付録 1 、付録 2)。リストを見ると、火山現 象に関する講演が最も多く、次いで、気象、地震 に関する講演となっている。見てお分かりのよう に、地球科学現象の多くは混相流と深い関わりが ある。例えば火山現象は、地下で生成されたマグ マが地表に到達し噴火する過程であるが、マグマ は結晶 (固体) +溶融した岩石（液体）十火山ガ ス（気体）の混合物であり、その流れの振る舞い が火山活動のスタイルに大きな影響を与える。

本特集では、日本地球惑星科学連合大会や東京 大学地震研究所での研究集会において話題提供 をして頂いた方々の中から、混相流に関係のある

* 2020.8.17 受付

** 明星大学理工学部機械工学系 干191-8506 東京都日野市程久保 2-1-1

TEL: (042) 591-9619 E-mail: ichiro.kumagai@meisei-u.ac.jp

*** 東京大学地震研究所

$\dagger$ 気象庁福岡管区気象台 
皆さんにご執筆をお願いした。地球惑星科学分野 のご専門の方はもちろん、流体物理やキッチンの 本家である調理学のご専門の方まで、幅広い分野 のトピックを集めることができた。また、コロナ 禍で多くの犠牲者が出ている状況の中、海外の研 究者の方にも無理を言ってご執筆頂いた。

いずれの論文も、身近な素材や身の回りのもの を使った実験から、とても興味深い結果が得られ ており、混相流の読者の皆様にも楽しんで頂ける 内容になっていると信じている。著者の皆様には、 ご自身の研究の他、当該研究分野の簡単なレビュ 一をして頂くようお願いしているので、研究背景 を理解して頂けると思われる。単に楽しいだけで はなく、学問的にも価值の高い内容になっている。

\section{2. キッチン地球科学とは?}

\section{1 活動のきっかけ}

「キッチン地球科学」について初めて知る方も 多いと思われるので、以下、その活動について簡 単に記しておきたい。

地球惑星科学で観られる流体運動に関わる現 象は、考慮すべき物性パラメータが多く（単相で ない、線形でない、など)、時間的にも空間的に も大きなスケールを対象とした現象が多い。本活 動を開始した 2000 年頃、コンピューターの計算 能力の急速な向上もあって、流体力学的なスケー リングが難しい室内のアナログ流体実験よりも、 数值シミュレーションの方が主流になりつつあ った。我々はそのとき、地球惑星科学において「ア ナログ流体実験の役割は終わったのではない か?」という疑問を投げかけたのがそもそもの出 発点であった。

また大学院教育においても、数值シミュレーシ ヨンを用いた研究が増え、教員から与えられたテ ーマに疑問を持たずに、ひたすら机の前に座って プログラムを書くような学生が増えた。こうした 状況を憂慮し、計算機の中の地球を相手にするだ けではなく、実験を実際に観て自然のリアルな現 象を実感・共感し、学生に深く考える機会を与え たいという願いもあった。

\section{2 「キッチン地球科学」セッション立ち上げ}

学生をはじめ誰でも気軽に実験を始められる ようにするには、実験に必要な道具や素材が安価 かつ容易に入手できる必要がある。寺田寅彦の随 筆「茶わんの湯」(1922)では、日常の観察から地
球惑星科学現象を深く広く考察したように、我々 の日常にあるものを使って実験をし、それらの現 象から地球惑星科学現象を考察し、現象を支配寸 る物理の理解や新しい問題の発見のきっかけを 作ることはできないかと考えた。家の中を見渡し たとき、様々な実験の素材が揃っていて、温度調 節ができ、しかも失敗しても問題なさそうな場所 となれば「キッチンで実験！」となるのは自然の 流れであった。そこで著者の栗田らは、2001 年 の日本地球惑星科学連合大会において「キッチン 地球科学」のセッションを立ち上げ、以来、途中 休止期間（2009 年〜2015 年）を挟むこともあっ たが、現在までその活動が続いている(付録 1)。

これまでに「地学現象をわかりやすく教授する ためのツール」として、アウトリーチや初等・中 等教育の現場に大きな影響を与え、新聞の科学欄 や Newton などの科学雑誌に取り上げられるなど、 地球惑星科学や地学教育の分野で高い評価を得 てきた。皆さんの中にはNHKの『ブラタモリ』 などの実験をご覧になった方もいらっしゃると 思うが、身近な物を使った「キッチン地球科学」 実験は、数值シミュレーションの動画よりも、現 象をより実感的に理解するには効果的であった。

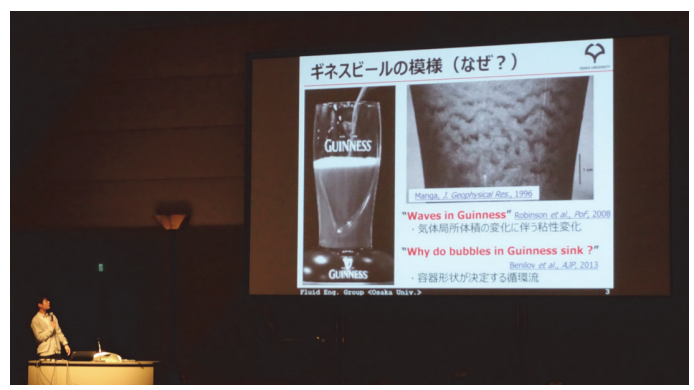

Photo 1 Invited presentation by Dr. Watamura (Osaka Univ.) in the JpGU2017 public session of Kitchen Earth Science.

\section{3 「キッチン地球科学 : 動手脳刺激実験」}

近年、東京大学地震研究所の共同利用 (2017 〜2019)ににおて「キッチン地球科学 : 動手頭脳 刺激実験の模索」というテーマで研究集会を行な ってきた（付録 2)。高等学校や大学の教員、博 物館関係者、研究所、メディア等、幅広い分野の 方々が集まり、科学、教育、社会との関わりなど、 多岐に渡って闊達な議論が交わされた (Photo 2)。 


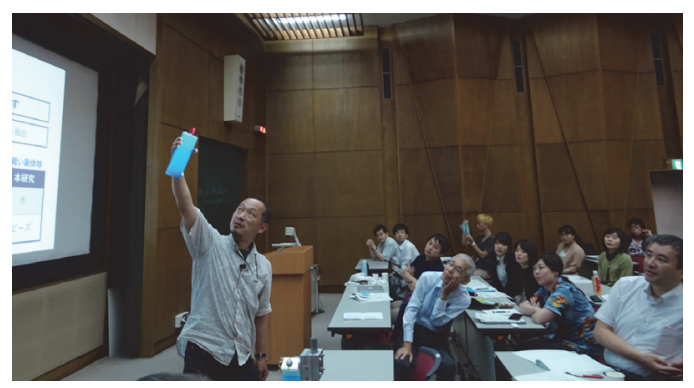

Photo 2 Presentation by Prof. Toramaru (Kyushu Univ.) in the workshop on Kitchen Earth Science (Earthquake Research Institute: ERI, Univ. Tokyo, Aug. 2017).

これまで、高校の地学実験や大学の教養実験で は、「答えがわかっている、あるいは、予想がつ きやすい基礎実験」が多かった。もちろん科学で は基礎が重要であるが、完成された実験であるが 故に実験がルーティン化され、学生・生徒にとっ て実験を行なったときの感動が薄く、つまらない ものも多いのが実状である。また、教員の立場か らすると、(これはあまり書いてはいけないかも しれないが）毎回同じ結果で、同じようなレポー 卜を見せられるのは正直なところ苦痛であり、全 く「わくわく」しない。

そこで最近我々は「考える地学実験」として「自 ら手を動かして不確定要素の詰まった実験をす る。結果のわからない実験をする」ことの重要性 について模索している。予想外の結果は、新たな 問題の発見の卵であり、自然現象に対する驚きや 感動を与え、科学的探究心の原動力になる。地球 惑星科学現象に多く観られる混相流は、単相流に 比べて不確定要素が詰まっており、こうした実験 には最適であると思われる。

通常の学会では講演時間が 10〜 15 分程度と限 られ、多少フォーマルな部分があるため、率直な 議論を交わしにくい。それを補うため、本研究集 会では、十分な講演時間 (30 分程度) を確保し、 議論の場を設けた。また初めての試みとして「ラ イブ・キッチン地球科学」と称し、講演の合間に 実験の実演発表をする時間を設けた（Photo 3, Photo 4)。参加者の目の前で起きている現象をそ の場で議論でき、論文では書かれていない実験の ノウハウなど、生情報の交換にも大いに役立った。

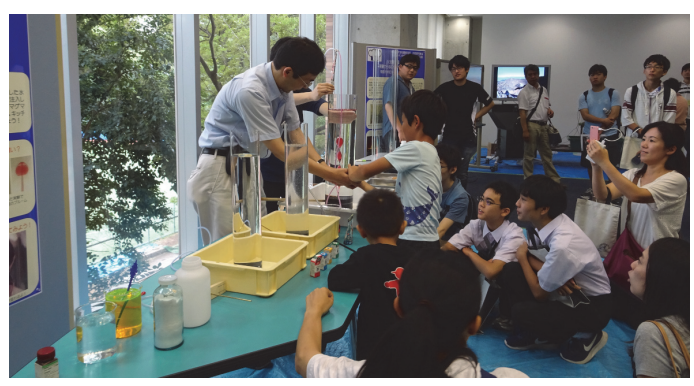

Photo 3 Live Kitchen Earth Science experiments demonstrated by Prof. Kumagai and his students (Meisei Univ.) in the workshop on Kitchen Earth Science (ERI, Univ. Tokyo, Aug. 2017).

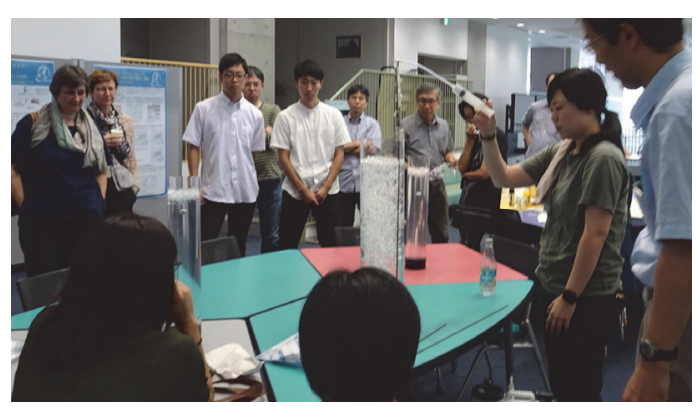

Photo 4 Live Kitchen Earth Science experiments on motion of air bubbles and solid spheres in a layer of deformable gel beads (SAPs, [3]) (the 2nd workshop on Kitchen Earth Science, ERI, Univ. Tokyo, Sept. 2018).

\section{4 海外での状況}

海外に目を向けると、いわゆる Education and Public Outreach (EPO)が欧米では活発に行なわれ ている。地球惑星科学の分野では、米国地球物理 学会 (American Geophysical Union: AGU) や欧州地 球科学連合 (European Geosciences Union: EGU) において多くの教育セッションがあり、実験を主 体とした Hands-on experiments も盛んに行なわれ ている。また博物館においても、子供たちが実験 を通して学ぶ施設が充実しており、例えば、San Francisco の Exploratorium や Paris $の$ Palais de la découverte など、大人も楽しめる秀逸な博物館が ある。またフランスでは、Fête de la science（日本 
の科学技術週間のような、大学・研究所のオープ ン・ラボ) などで実験が披露されている (Photo 5)。

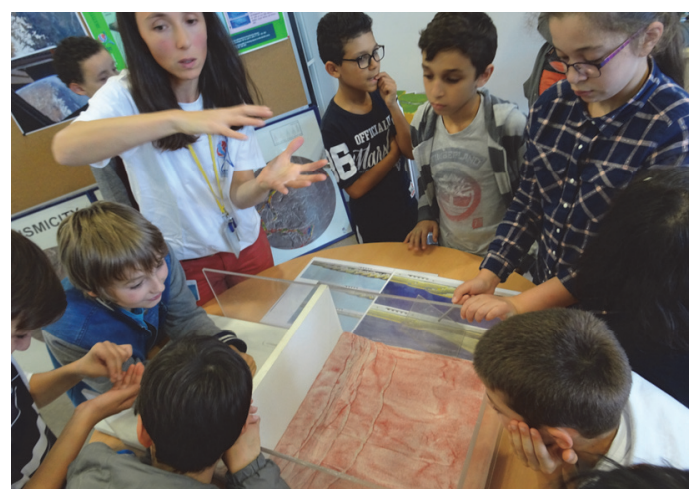

Photo 5 Sandbox experiments of fault formation. (Fête de la science 2018, Institut de Physique du Globe de Paris: IPGP, France, Oct. 2018).

しかしいずれも「現象をわかりやすく教授する ためのツール」に留まっており、「自ら手を動か して不確定要素の詰まった実験をする。結果のわ からない実験をする」という観点では行なわれて いない。

昨年、著者の栗田が EGU の国際会議（EGU General Assembly 2020）に「考える地学実験」に関 するセッション提案をし、"Kitchen Earth Science, as a brain-stimulating laboratory experiment”という セッションが採択された。今年は、残念ながらコ ロナ禍によるオンライン開催となったが、今後も こうした活動を継続して行きたいと考えている。

\section{3. おわりにーコロナ禍での役割}

本特集の前書きを終えるにあたり、コロナ禍で の学部実験に関する話をしたい。

多くの大学と同様、熊谷が勤務する明星大学で も、前期の講義を全て非対面（オンライン）で実 施することになった。そのとき問題となったのが、 実験や実習をどのように行なうかであった。対面 での実験は、感染リスクが生じるため、非対面で の実験が推奨された。学生による実験の実施が困 難である場合には、例えば、教員が実験を行なっ ているところを撮影し、それをネット上に流して 学生に視聴させるオンライン実験を行なうなど している。学生を実験設備のある大学に密な状態
で集められない以上、仕方のない方法であるが、 キッチン地球科学的な実験を提示できれば、学生 自身の手で実験を実施することができる。

自身の例で恐縮だが、熊谷の場合 (理工学部機 械工学系の学生実験)、キッチンでできるトリチ エリの定理の実験を行なった。学生が用意するも のは、ペットボトル、ペットボトルに小孔（オリ フィス）を開ける画鋲、物差し、ペットボトルに 目盛をつける油性ペン、そして時計（スマホのス トップウォッチ) だけである。実験では、ペット ボトルに水を入れて、トリチェリの定理による流 出量の理論値と実験データとの比較を行なう。こ れを基本の実験とし、「さらなる追加実験や工夫 をした学生には加点する」としたところ、小孔の サイズや数を変えたり、水以外の流体を試したり、 界面活性剂を入れたりなど、各自が工夫を凝らし、 楽しんで実験を実施し、独自の考察をしてくれた。

今般、コロナ禍で気が沈むことが多い中、「キ ッチン地球科学」の新たな可能性を見出したこと に小さな喜びを感じている。

\section{謝 辞}

コロナ禍の困難な状況の中、本特集の執筆にご 協力下さった皆様、「混相流」の編集委員および 関係者の皆様、キッチン地球科学の運営にご協力 下さった全ての皆様に感謝の意を表する。

「キッチン地球科学」研究集会は、2017 年度 ～2019 年度の東京大学地震研究所共同利用の援 助を受けた。また本研究は JSPS 科研費 $18 \mathrm{~K} 18629$ の助成を受けた。

\section{参考文献}

[1] Watamura, T., Iwatsubo, F., Sugiyama, K., Yamamoto, K., Yotsumoto, Y. and Shiono, T., Bubble Cascade in Guinness Beer is Caused by Gravity Current Instability, Scientific Reports, $\begin{array}{llll}\text { Vol. } & 9, & 5718 & \text { (2019). }\end{array}$ https://doi.org/10.1038/s41598-019-42094-0

[2] Manga, M., Waves of bubbles in basaltic magmas and lavas, Journal of Geophysical $\begin{array}{lll}\text { Research, Vol. } 101 & \text { (B8), pp.17457-17465 }\end{array}$ (1996).

[3] Sgreva, N.R., Davaille, A., Kumagai, I. and Kurita, K., Interaction between a falling sphere and the structure of a non-Newtonian yield-stress fluid, Journal of Non-Newtonian Fluid Mechanics, vol. 284 (2020) 104355. https://doi.org/10.1016/j.jnnfm.2020.104355 
付録 1

\section{地球惑星科学連合大会 パブリックセッション 「キッチン地球科学」講演一覧}

2017 年度

佐藤博明・佐藤鋭一（神戸大学）

「粘性流体中の粒子の沈降様式を観察する： 簡単な材料による 2 相流の実験」

宮鍋慶介（東北大学）ら

「科学技術を用いた防災教育の効果に関する 検討」

久利美和（東北大学災害科学国際研究所）

「科学教育と防災教育と論理的思考教育の融 合の試みの中での簡易模擬実験」

野口里奈 (東京工業大学 理学院 火山流体研究セ

ンター) ら

「水飴でルートレス噴火は起こせるか? -爆 発的なべっこう飴一」

菅野 洋・市原美恵（東京大学地震研究所）

「アウトリーチ活動のための水あめ噴火噴火 実験」

栗田 敬（東京大学地震研究所）

$\lceil$ Review on rheology of complex fluids usable in kitchen earth science $\rfloor$

千葉達朗（アジア航測株式会社）ら

「赤色立体地図模型を使用したアナログモデ ル実験」

山田美幸（日本大学）ら

「ペレーの毛」の形成に関する流れの可視化 実験」

熊谷一郎・市村典敬 (明星大学)

「キッチン地球科学者のための物性測定：簡 易落球法と画像解析を用いたレオロジー 測定」

桑野 修（海洋研究開発機構）ら

「実習・実演のための寒天ゲルを用いた室内 地震探査実験」

2018 年度

手塚 寛（東北大学）ら

「液状化実験を活用した防災教育」

熊谷一郎 (明星大学) - 山田美幸 (日本大学)

「災害教育のための火災旋風の実験」

庄司真史（株式会社ライブ・アース）ら

「震源の 4 次元可視化ツール開発 熊本地震 の理解を深める教育教材として〜」

河合研志 (東京大学・理) - 内出崇彦（産総研）

「P 波の初動極性分布を用いた震源決定の教 材 : 2011 年東北地方太平洋沖地震の発生 前後の飛騨地方の微小地震を例にとって」

渡村友昭（大阪大学）ら

「ギネスビールの泡が作る模様と流れの科 学」

熊谷一郎 (明星大学) ら

「キッチン地球科学」活動報告 : 地震研究所 一般公開および共同利用研究集会 2017」

栗田 敬 (東京大学) ・熊谷一郎 (明星大学)
「科学的興味を誘起するキッチン地球科学的 材料 (1)

山田美幸（日本大学）ら

「火山噴火における「ペレーの涙」はどのよ うにしてできるのか?」

皆川晶子 (お茶の水女子大学) ら

「推進する粒子集団による対流現象」

2019 年度

古川邦之 (愛知大学) ら

「ゼロカロリー甘味料を使った火成岩の結晶 成長を理解する実験」

金丸龍夫 (日本大学) ・藤縄明彦（茨城大学）

$\lceil$ Making volcanic edifice with edible lava

秋葉祐里（山梨大学）ら

「柱状節理の幾何パターン解析と澱粉ペース トによるアナログ実験」

江川嘉寿也・桂木洋光 (名古屋大学)

$\lceil$ Viscoelastic characterization of a solid projectile impact onto a dense potato starch suspension」

下川倫子 (福岡工業大学) ・坂口英継 (九州大学)

「混合粉体がつくる砂山のパターン形成一縞 パターンと分離パターンの選択メカニズ ム—」

はしもとじょーじ・小汐由介 (岡山大学)

「電子工作キット GC10 のガイガー＝ミュラ 一計数管で放射線量を測る」

久利美和 (東北大学災害科学国際研究所)

「学際教育でのキッチン地球科学の活用」

市原美恵（東京大学地震研究所）ら

「水あめ噴火実験を通して噴火様式を決める 条件について考える」

栗田 敬 (東京大学) ら

「爆発するかりんとう：絶対やってはいけな いキッチン実験」

2020 年度（オンライン開催）

千葉達朗 (アジア航測株式会社)

「ウレタン火山噴火実験の発案とその改良」

市原美恵（東京大学地震研究所）

「ストロー笛に学ぶ火山性微動の発生・停止 機構」

久好圭治（大阪府立大手前高校）

「重力の魔術師をめざして〜微小重力発生 装置と重力可変装置の製作と実験〜」

庄司大悟（東京工業大学・JAXA）

「Introduction of Enceladus Farm: Growing plants simulating the composition of Enceladus' subsurface ocean.

下川倫子（福岡工業大学）

「対流構造が作るフラクタルパターンーミル クコーヒーから考える地球科学一」

はしもとじょーじ (岡山大学)

$\lceil\mathrm{CO} 2$ 濃度を測ると換気したくなる」

神崎正美 (岡山大学)

「ホットプレートと偏光シートを使った硝酸 アンモニウムの相転移観察」 


\section{付録 2}

\section{東京大学地震研究所共同利用研究集会} キッチン地球科学: 動手頭脳刺激実験 講演一覧

2017 年度

木村龍治 (東京大学名誉教授)

「模型実験で理解する気象現象、特に重力に よる安定性・不安定性の効果」

野口里奈 (東京工業大学)

「加熱シロップで理解するマグマ水蒸気爆発 の本質」

林信太郎（秋田大学教育文化学部地学研究室）

「教師教育のためのキッチン溶岩、一マヨネ 一ズとコンデンスミルクー」

市原美恵（東京大学地震研究所）

「東大・初年次ゼミ理科『デジタル地球科学』 でアナログ実験」

豊田丈典（博報堂）

「伝わらないことから、一科学の外から、科 学コミュニケーションを考える一」

下川倫子（福岡工業大学）

「自然が作るラテアート」

芳田泰基（北海道大学 工学部）

「流動食品のレオロジーを測る」

井上陽司・益子岳史 (静岡大学)

「作動流体の相転移が引き起こす熱対流現象 への挑戦

佐藤博明・佐藤鋭一

「マグマ溜りでの結晶沈降モードを考える： 空き瓶を使った簡易実験」

渡村友昭（大阪大学 工学部）

「ギネスビールの泡の対流 : そもそも何を見 ているのか?」

寅丸敦志 (九州大学)

「ギネスで乾杯！....の前に」

栗田 敬 (東京大学名誉教授)

「キッチン地球科学の課題」

市原美恵（東京大学地震研究所）

「地震研究所一般公開 with キッチン地球科 学」

2018 年度

栗田 敬 (Kitchen Wanderer，東京大学名誉教授）

「アナログ実験の興隆と衰退、そして再興」

Anne Davaille (Univ. Paris Sud / CNRS)

$\lceil$ Plumes in the Earth mantle: lessons from sugar syrup and hair gel $\rfloor$

秋葉祐里 (山梨大学)

「亀裂パターンのアナロジー：乾燥デンプン ペーストと冷却マグマ」

香西みどり（お茶の水女子大学調理学研究室）

「膨化を伴う調理でおこる破裂と亀裂」

Angela Limare (パリ地球物理学研究所 IPGP)

「電子レンジを用いた内部発熱対流の実験」

下川倫子 (福岡工業大学)

「沈降する液滴の分裂現象」

熊谷一郎 (明星大学)
「沈降する固体球の合体現象」

平松和彦 (福山市立大学)

「白砂糖とグラニュー糖を使った表層雪崩実 験」

永弘進一郎（仙台高専）

「片栗粉ペーストのずり粘稠化メカニズム」

久利美和 (東北大学)

「大学院分野融合教育でのキッチン地球科学 の活用

井上陽司 (静岡大学) ら

「感温性ゲルを用いた熱対流実験一流体相転 移が引き起こす特異な現象への挑戦一」

2019 年度

熊谷一郎 (明星大学)

「はじめに: キッチン地球科学の活動報告と 今後の展開」

吉野 隆 (東洋大学)

「シンメトリーおにぎりーキッチン幾何学 一」

庄司大悟（東京工業大学 ELS）

「ゆらぎのあるレゴによる形のない形：学問 と遊びの間で」

栗田 敬 (Kitchen Wanderer, 東京大学名誉教授) 「台所の音」

益子岳史 (静岡大学)

「身近な機械で体験する熱力学 一小学生〜 高校生向け理科教室の試み一」

久利美和 (気象庁 福岡管区気象台)

「地域防災教育でのキッチン地球科学の活 用」

久好圭治（大阪大手前高等学校）

「重力の魔術師をめざして～重力可変装置 を用いた実験について〜」

栗田玲（首都大学東京）

「2 成分混合系における異常対流」

Angela Limare (パリ地球物理学研究所 IPGP,

France)

$\lceil$ Convection in a microwave oven: application to planetary bodies $\rfloor \& \quad$ Fête de la science in IPGP $\rfloor$

下川倫子 (福岡工業大学)

「コロイド凝集により形成される星形パター ン」

Nicolo Rubens Sgreva（パリ南大学 Univ. Paris Sud, France)

$\lceil$ Interaction between a falling sphere and the texture of a complex fluid: insights from hydrogels

秋葉祐里 (山梨大学)

「デンプンでマグマしてみよう：アナログ実 験の再検討」

はしもとじょーじ（岡山大学）

「室内の CO2 を測る」

※著者が 3 名以上の場合、記載は筆頭著者のみと させて頂いた。 